\title{
Studi Peningkatan Kualitas Pelayanan Penyulang Menggunakan Load Break Switch(LBS) Three Way
}

\author{
I Kadek Hery Samudra ${ }^{1}$, I Gede Dyana Arjana ${ }^{2}$, I Wayan Artha Wijaya ${ }^{3}$
}

\begin{abstract}
In a distribution system, the quality of the reliability can be seen from the duration of the power outage or SAIDI (System Average Interruption Duration Index) and how often the power outage happened in a unit of time or SAIFI (System Average Interruption Frequency Index). One of the ways that had been done by PT. PLN (Persero) Bali distribution South Bali area's network to reduce the number of customers' power outage when the interference occurred is by installing Load Break Switch (LBS) three way. The results of the calculation of quality reliability based on outage of Gunung Agung feeder after installation LBS Three Way with SAIFI is $\mathbf{0 . 9 8 9 6 8 8 5 2 6}$ and SAIDI is $\mathbf{0 . 6 8 3 9 1 3 2 5 3}$, while of Imam Bonjol feeder after installation LBS Three Way with SAIFI is $\mathbf{0 . 6 8 3 9 1 3 2 5 3}$ and SAIDI is 3.908243775 . The results of analysis influence installation LS Three Way to customer DB0133 (United Overseas Bank) thai is customer DB0133 no experience power outage if disruption of Gunung Agung feeder because customer in maneuvering for Imam Bonjol feeder. Based on the analysis of maneuverability load on Gunung Agung and Imam Bonjol's feeders after the installation of LBS three way. Gunung Agung's feeder was capable in maneuvering customers section I and III from Imam Bonjol's feeder and Imam Bonjol's feeder was capable in maneuvering customers section III, IV, and V from Gunung Agung's feeder.
\end{abstract}

Intisari- Pada sistem distribusi, kualitas keandalan dapat dilihat dari lamanya pemadaman atau SAIDI (System Average Interruption Duration Index) dan seberapa sering pemadaman terjadi dalam satuan waktu atau SAIFI (System Average Interruption Frequency Index). Sebuah upaya yang telah dilakukan oleh PT. PLN (persero) Distribusi Bali AJ Bali Selatan untuk mengurangi jumlah pelanggan padam saat terjadi gangguan yaitu dengan cara pemasangan LBS Three Way.

Hasil perhitungan kualitas keandalan berdasarkan angka keluaran pada penyulang Gunung Agung setelah pemasangan LBS Three Way yaitu SAIFI sebesar 0.989688526 dan SAIDI sebesar 5.737530618, sedangkan pada penyulang Imam Bonjol setelah pemasangan LBS Tree Way yaitu SAIFI sebesar 0.683913253 dan SAIDI sebesar 3.908243775. Hasil analisa pengaruh pemasangan LBS Three Way terhadap pelanggan DB0133 (United Overseas Bank) yaitu pelanggan pada DB133 tidak mengalami pemadaman apabila terjadi gangguan pada penyulang Gunung Agung karena pelanggan DB0133 dapat dimanuver oleh penyulang Imam Bonjol.

Berdasarkan perhitungan kemampuan manuver beban pada penyulang Gunung Agung dan Imam Bonjol, dapat dikatakan penyulang Gunung Agung mampu memanuver beban seksi I dan III pada penyulang Imam Bonjol, dan penyulang Imam Bonjol mampu memanuver beban seksi III, IV dan V pada penyulang Gunung Agung.

Kata Kunci- Keandalan Sistem, Indeks keandalan, LBS Three Way.

${ }^{1}$ Mahasiswa, Jurusan Teknik Elektro dan Komputer Fakultas Teknik Universitas Udayana, Jalan Kampus Bukit Jimbaran

${ }^{2,}{ }^{3}$ Dosen,Jurusan Teknik Elektro dan Komputer Fakultas Teknik Universitas Udayana, Jalan Kampus Bukit Jimbaran Badung Bali 80361

\section{PENDAHULUAN}

Sistem tenaga listrik yang andal dan energi listrik dengan kualitas yang baik atau memenuhi standar, mempunyai kontribusi yang sangat penting bagi kehidupan masyarakat moderen. Peranan energi listrik yang dominan dibidang industri, telekomunikasi, teknologi informasi, pertambangan, transportasi umum, dan lain-lain, yang semuanya itu dapat beroperasi karena tersedianya energi listrik. Perusahaan perusahaan yang bergerak diberbagai bidang sebagaimana disebutkan diatas, akan mengalami kerugian cukup besar jika terjadi pemadaman listrik secara tiba - tiba atau tegangan listrik yang tidak stabil, dimana aktifitas dari perusahaan akan terhenti atau produk yang dihasilkannya menjadi rusak.

Salah satu cara yang telah dilakukan oleh PT. PLN (Persero) Distribusi Bali area jaringan Bali selatan untuk mengurangi jumlah pelanggan padam saat terjadi gangguan yaitu dengan pemasangan Load Break Swich (LBS) three way. Pemasangan Load Break Swich (LBS) three way ini diharapkan mampu untuk meningkatkan mutu pelayanan kepada pelanggan. Berdasarkan permasalahan diatas, maka dalam penelitian ini akan dilakukan analisa pengaruh pemasangan Load Break Switch (LBS) Three Way terhadap peningkatan mutu pelayanan penyulang terutama indeks keandalan SAIDI dan SAIFI.

\section{LOAD BREAK SWITCH TREE WAY}

Load Break Switch (LBS) Three Way merupakan saklar pemutus beban atau arus tiga fasa, dimana load break switch three way ini memiliki perbedan dari load break switch (LBS) secara umum. Perbedaan LBS Three Way ini menggunakan tiga saluran atau three way.

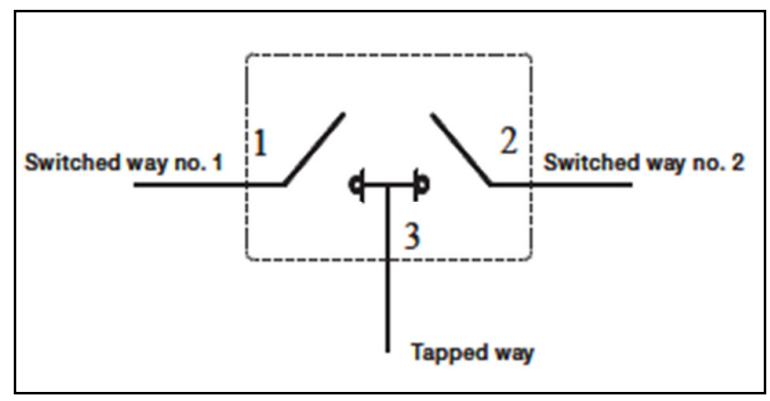

Gambar 1: Skema LBS Three Way

Pada jaringan distribusi LBS three way ini diaplikasikan pada persimpangan jaringan dan dapat juga sebagai penggabungan antara dua penyulang yang bertujuan untuk memanuverkan daya ke penyulang lain saat terjadi gangguan sehingga dapat memperkecil daerah pemadaman. 


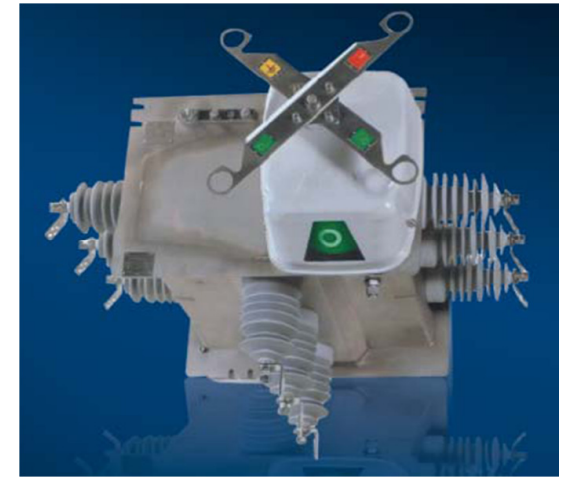

Gambar 2 : Load Break Switch Three Way

\section{A. Keandalan (Reliability) Pada Sistem Distribusi}

Keandalan dalam sistem distribusi adalah suatu ukuran ketersediaan/tingkat pelayanan penyediaan tenaga listrik dari sistem ke pemakai/pelanggan. Ukuran keandalan dapat dinyatakan sebagai seberapa sering sistem mengalami pemadaman, berapa lama pemadaman terjadi dan berapa cepat waktu yang dibutuhkan untuk memulihkan kondisi dari pemadaman yang terjadi (restoration). Sejumlah indeks sudah dikembangkan untuk menyediakan suatu kerangka untuk mengevaluasi keandalan sistem tenaga.

Evaluasi keandalan sistem distribusi terdiri dari indeks titik beban dan indeks sistem yang dipakai untuk memperoleh pengertian yang mendalam kedalam keseluruh pencapaian. Indeks keandalan tersebut antara lain : SAIDI, SAIFI dan AENS [5].

\section{1) Sistem Avarage Interuption Frequensi Index (SAIFI)}

Indeks ini didefinisikan sebagai jumlah rata-rata kegagalan yang terjadi per pelanggan yang dilayani oleh sistem per satuan waktu (umumnya pertahun). Persamaan SAIFI didefinisikan sebagai berikut:

SAIFI $=\frac{\sum_{i=1}^{m} C i}{\mathrm{~N}}=\frac{\text { Pemadaman }}{\text { Tahun }}$

Dimana :

$\mathrm{m}$ = jumlah pemadaman dalam satu tahun

$\mathrm{Ci}=$ jumlah konsumen yang mengalami pemadaman

$\mathrm{N}$ = jumlah konsumen yang dilayani

Indeks keandalan ini dapat juga dihitung dari angka keluaran komponen yang menyebabkan pemadaman.

SAIFI $=\frac{\sum \lambda \mathrm{kMk}}{\sum \mathrm{M}}=\frac{\text { Pemadaman }}{\text { Tahun }}$

Dimana :

$\lambda \mathrm{k}=$ angka keluaran $($ outage $)$ komponen

$\mathrm{Mk}=$ jumlah pelanggan pada titik beban

$\mathrm{M}=$ total pelanggan terlayani

I Kadek Hery Samudra : Studi Peningkatan Kualitas Pelayanan ...
2) Sistem Average Interruption Duration Index (SAIDI) Indeks ini didefinisikan sebagai nilai rata-rata dari lamanya kegagalan untuk setiap konsumen selama satu tahun. SAIDI didefinisikan sebagai berikut:

SAIDI $=\frac{\sum_{i=1}^{m} c i . t i}{\mathrm{~N}}=\frac{\mathrm{Jam}}{\text { Tahun }}$

Dimana :

$\mathrm{m}=$ jumlah pemadaman dalam satu tahun

$\mathrm{Ci}=$ jumlah konsumen yang mengalami pemadaman

ti = lamanya tiap-tiap pemadaman

$\mathrm{N}$ = jumlah konsumen yang dilayani

Indeks keandalan ini juga dapat dihitung dari angka keluaran komponen yang menyebabkan pemadaman dan waktu pemulihan pelayanan.

SAIDI $=\frac{\sum \mathrm{Uk} \mathrm{Mk}}{\sum \mathrm{M}}=\frac{\text { Pemadaman }}{\text { Tahun }}$

Dimana :

$\mathrm{Uk}=$ waktu perbaikan peralatan

$\mathrm{Mk}=$ jumlah pelanggan pada titik beban

$\mathrm{M}=$ total pelanggan terlayani

\section{METODE PENELITIAN}

Analisis dalam penelitian ini dilakukan dalam beberapa tahapan sebagai berikut :

1. Mengumpulkan data penyulang Gunung Agung dan Imam Bonjol : single line diagram penyulang, panjang saluran, beban, pelanggan masing-masing penyulang, LBS Tree Way, recloser, trafo

2. Menghitung SAIFI dan SAIDI kedua penyulang sebelum pemasangan LBS Three Way berdasarkan data gangguan

4. Menghitung SAIFI dan SAIDI kedua penyulang sebelum pemasangan LBS Three Way berdasarkan angka keluaran

5. Menghitung SAIFI dan SAIDI kedua penyulang setelah pemasangan LBS Three Way berdasarkan angka keluaran

6. Analisa pengaruh pemasangan LBS Three Way terhadap mutu pelayanan pelanggan DB133 (United Overseas Bank).

7. Menghitung kemampuan manuver beban pada penyulang Gunung Agung dan Imam Bonjol.

\section{HASIL DAN PEMBAHASAN}

A. Keandalan Penyulang Gunung Agung Sebelum Pemasangan LBS Three Way

Penyulang Gunung Agung adalah salah satu penyulang di PT. PLN (Persero) Distribusi Bali area jaringan Bali selatan dengan total panjang jaringan sekitar $8.470 \mathrm{Km} 2$, Penyulang Gunung Agung memiliki total daya terpasang 5,840 kVA dengan jumlah pelanggan sebanyak 3,364 pelanggan (PT. PLN (persero) area jaringan Bali selatan). Berdasarkan tabel 1 total gangguan yang terjadi pada penyulang Gunung Agung selama tahun 2012 sebanyak 8 kali dengan total waktu padam p-ISSN:1693 - 2951; e-ISSN: 2503-2372 
selama 11.64 jam. Dengan mengasumsikan jumlah pelanggan selama tahun 2012 adalah tetap sebesar 3,364 pelanggan, maka nilai SAIFI dan SAIDI penyulang Gunung Agung sebelum pemasangan LBS Three Way dapat dihitung sebagai berikut :

TABEL I

DATA GANGGUAN PADA PENYULANG GUNUNG AGUNG TAHUN 2012 (SEBELUM PEMASANGAN LBS THREE WAY)

\begin{tabular}{|c|c|c|c|c|c|c|}
\hline \multicolumn{2}{|c|}{ B } & \multicolumn{2}{|c|}{ PMT } & \multicolumn{2}{c|}{$\begin{array}{c}\text { Lock Out LBS } \\
\text { Merta Jaya }\end{array}$} & \multicolumn{2}{c|}{$\begin{array}{c}\text { Lock Out Recloser } \\
\text { Siwa Plasa }\end{array}$} \\
\cline { 2 - 7 } $\begin{array}{c}\text { a } \\
\text { n }\end{array}$ & Kali & $\begin{array}{c}\text { Lama } \\
\text { Padam } \\
\text { (Jam) }\end{array}$ & Kali & $\begin{array}{c}\text { Lama } \\
\text { Padam } \\
\text { (Jam) }\end{array}$ & Kali & $\begin{array}{c}\text { Lama } \\
\text { Padam } \\
\text { (Jam) }\end{array}$ \\
\hline Jan & 2 & 7,24 & 0 & 0 & 0 & 0 \\
\hline Feb & 0 & 0 & 0 & 0 & 0 & 0 \\
\hline Mar & 0 & 0 & 0 & 0 & 0 & 0 \\
\hline Apr & 0 & 0 & 0 & 0 & 0 & 0 \\
\hline Mei & 0 & 0 & 0 & 0 & 0 & 0 \\
\hline Jun & 2 & 0,34 & 0 & 0 & 0 & 0 \\
\hline Jul & 0 & 0 & 0 & 0 & 0 & 0 \\
\hline Agu & 0 & 0 & 0 & 0 & 0 & 0 \\
\hline Sep & 1 & 0,34 & 0 & 0 & 0 & 0 \\
\hline Okt & 0 & 0 & 1 & 1,34 & 0 & 0 \\
\hline Nov & 1 & 1,16 & 0 & 0 & 1 & 1,22 \\
\hline Des & 0 & 0 & 0 & 0 & 0 & 0 \\
\hline Total & 6 & 9,08 & 1 & 1,34 & 1 & 1,22 \\
\hline
\end{tabular}

1) Berdasarkan persamaaan (1), maka dapat dihitung SAIFI untuk bulan Januari 2012 :

SAIFI $=\frac{\text { Jumlah Pelanggan Padam }}{\text { Jumlah Pelanggan Terlayani }}$

SAIFI $=\frac{(\text { Jumlah pemadaman } \times \text { PU keluar } \times \text { Plg Padam })}{\text { Jumlah Pelanggan Terlayani }}$

SAIFI $=\frac{(1 \times \text { PMT } x \text { Plg padam })+(1 \times \text { PMT } x \text { Plg padam })}{\text { Jumlah Pelanggan Terlayani }}$

$\mathrm{SAIFI}=\frac{(1 \mathrm{kali} \times 1 \times 3,364 \mathrm{plg})+(1 \mathrm{kali} \times 1 \times 3,364 \mathrm{plg}}{3,364 \text { pelanggan }}$

SAIFI = 2 Kali/Pelanggan $/$ Tahun

2) Berdasarkan persamaaan (3), maka dapat dihitung SAIDI untuk bulan Januari 2012:

SAIDI $=\frac{\text { Lama Pelanggan Padam }}{\text { Jumlah Pelanggan Terlayani }}$

SAIDI $=\frac{(\text { Lama pemadaman } \mathrm{x} \text { PU keluar } \mathrm{x} \text { Plg Padam })}{\text { Jumlah Pelanggan Terlayani }}$

$$
\begin{aligned}
& =\frac{(5,06 \times \text { PMT } \times \text { Plg padam })+(2.18 \times \text { PMT } \times \text { Plg padam }}{\text { Jumlah Pelanggan Terlayani }} \\
& =\frac{(5,06 \text { jam } \times 1 \times 3,364 \mathrm{plg})+(2,18 \text { jam } \times 1 \times 3,364 \mathrm{plg})}{3,364 \text { pelanggan }} \\
& \text { SAIDI }=7,24 \mathrm{Jam} / \text { Pelanggan/Tahun }
\end{aligned}
$$

Dengan cara yang sama diperoleh nilai SAIFI dan SAIDI penyulang Gunung Agung sebelum pemasangan LBS Three Way seperti tabel 2.

TABEL II

HASIL PERHITUNGAN SAIFI DAN SAIDI PENYULANG GUNUNG AGUNG SEBELUM PEMASANGAN LBS THREE WAY BERDASARKAN DATA GANGGUAN

\begin{tabular}{|c|c|c|c|c|c|}
\hline Bulan & $\begin{array}{c}\text { Peralatan } \\
\text { Trip/Out }\end{array}$ & $\begin{array}{c}\text { Jumlah } \\
\text { Gangguan } \\
\text { (Kali) }\end{array}$ & $\begin{array}{c}\text { Lama } \\
\text { Padam } \\
\text { (Jam) }\end{array}$ & SAIFI & SAIDI \\
\hline Jan & PMT & 2 & 7,24 & 2 & 7,24 \\
\hline Feb & 0 & 0 & 0 & 0 & 0 \\
\hline Mar & 0 & 0 & 0 & 0 & 0 \\
\hline Apr & 0 & 0 & 0 & 0 & 0 \\
\hline Mei & 0 & 0 & 0 & 0 & 0 \\
\hline Jun & PMT & 2 & 0,34 & & 0,34 \\
\hline Jul & 0 & 0 & 0 & 0 & 0 \\
\hline Agu & 0 & 0 & 0 & 0 & 0 \\
\hline Sept & PMT & 1 & 0,34 & 1 & 0,34 \\
\hline Okt & Cut Out & 1 & 1,34 & 0,018 & 0,025 \\
\hline Nov & PMT, & 2 & 2,38 & 1,33 & 1,574 \\
\hline Res & 0 & 0 & 0 & 0 & 0 \\
\hline Total & - & 8 & 11,64 & 6,348 & 9,519 \\
\hline
\end{tabular}

Dari hasil perhitungan diperoleh nilai SAIFI penyulang Gunung Agung sebelum pemasangan LBS Three Way sebesar $6.348 \mathrm{kali} /$ pelanggan/tahun, untuk SAIDI sebesar 9.519 jam/pelanggan/tahun.

\section{B. Keandalan Penyulang Imam Bonjol Sebelum Pemasangan LBS Three Way}

Penyulang Imam Bonjol adalah salah satu penyulang di . PLN (Persero) Distribusi Bali area jaringan Bali selatan dengan total panjang jaringan sekitar $5.906 \mathrm{Km} 2$, penyulang Imam Bonjol memiliki total daya terpasang 5,962 kVA dengan jumlah pelanggan sebanyak 2,987 pelanggan (PT. PLN (persero) area jaringan Bali selatan).

Berdasarkan tabel 3 total gangguan yang terjadi pada penyulang Imam Bonjol selama tahun 2012 sebanyak 2 kali dengan total waktu padam selama 0.30 jam. Dengan mengasumsikan jumlah pelanggan selama tahun 2012 adalah tetap sebesar 2,987 pelanggan, maka nilai SAIFI dan SAIDI penyulang Imam Bonjol sebelum pemasangan LBS Three Way dapat dihitung sebagai berikut : 
1) Berdasarkan persamaan (1), maka dapat dihitung SAIFI untuk bulan Februari 2012:

SAIFI $=\frac{\text { Jumlah Pelanggan Padam }}{\text { Jumlah Pelanggan Terlayani }}$

SAIFI $=\frac{\text { (Jumlah pemadaman } \mathrm{x} \text { PU keluar } \mathrm{x} \text { Plg Padam) }}{\text { Jumlah Pelanggan Terlayani }}$

SAIFI $=\frac{(1 \text { Kali } x \text { PMT } x \text { Plg padam })}{\text { Jumlah Pelanggan Terlayani }}$

TABEL III

DATA GANGGUAN PADA PENYULANG IMAM BONJOL TAHUN 2012 (SEBELUM PEMASANGAN LBS THREE WAY)

\begin{tabular}{|c|c|c|c|c|c|c|}
\hline \multirow{2}{*}{$\begin{array}{c}\text { B } \\
\text { u } \\
\text { a } \\
n\end{array}$} & \multicolumn{2}{|c|}{ PMT } & \multicolumn{2}{c|}{$\begin{array}{c}\text { Lock Out LBS } \\
\text { Merta Jaya }\end{array}$} & $\begin{array}{c}\text { Lock Out Recloser } \\
\text { Siwa Pasa }\end{array}$ \\
\cline { 2 - 7 } & Kali & $\begin{array}{c}\text { Lama } \\
\text { Padam } \\
(\text { Jam })\end{array}$ & Kali & $\begin{array}{c}\text { Lama } \\
\text { Padam } \\
\text { (Jam) }\end{array}$ & Kali & $\begin{array}{c}\text { Lama } \\
\text { Padam } \\
\text { (Jam) }\end{array}$ \\
\hline Jan & 0 & 0 & 0 & 0 & 0 & 0 \\
\hline Feb & 1 & 0,06 & 0 & 0 & 0 & 0 \\
\hline Mar & 0 & 0 & 0 & 0 & 0 & 0 \\
\hline Apr & 0 & 0 & 0 & 0 & 0 & 0 \\
\hline Mei & 0 & 0 & 0 & 0 & 0 & 0 \\
\hline Jun & 0 & 0 & 0 & 0 & 0 & 0 \\
\hline Jul & 0 & 0 & 0 & 0 & 0 & 0 \\
\hline Agu & 0 & 0 & 0 & 0 & 0 & 0 \\
\hline Sep & 1 & 0,24 & 0 & 0 & 0 & 0 \\
\hline Okt & 0 & 0 & 0 & 0 & 0 & 0 \\
\hline Nov & 0 & 0 & 0 & 0 & 0 & 0 \\
\hline Des & 0 & 0 & 0 & 0 & 0 & 0 \\
\hline Total & 2 & 0,30 & 0 & 0 & 0 & 0 \\
\hline
\end{tabular}

SAIFI $=\frac{(1 \mathrm{kali} \times 1 \times 2,987 \mathrm{plg})}{2,987 \text { pelanggan }}$

\section{SAIFI = 1 Kali/Pelanggan/Tahun}

2) Berdasarkan persamaan (3), maka dapat dihitung SAIDI untuk bulan Februari 2012 :

SAIDI $=\frac{\text { Lama Pelanggan Padam }}{\text { Jumlah Pelanggan Terlayani }}$

SAIDI $=\frac{(\text { Lama pemadaman } \mathrm{x} \text { PU keluar } \mathrm{x} \text { Plg Padam })}{\text { Jumlah Pelanggan Terlayani }}$

SAIDI $=\frac{(0,06 \mathrm{Jam} \times 1 \times 2,987 \mathrm{plg})}{2,987 \text { pelanggan }}$

SAIDI $=$ 0,06 Jam/Pelanggan $/$ Tahun

Dengan cara yang sama diperoleh nilai SAIFI dan SAIDI penyulang Imam Bonjol sebelum pemasangan LBS Three Way seperti tabel 4.
TABEL IV

HASIL PERHITUNGAN SAIFI DAN SAIDI PENYULANG IMAM BONJOL SEBELUM PEMASANGAN LBS THREE WAY BERDASARKAN DATA GANGGUAN

\begin{tabular}{|c|c|c|c|c|c|}
\hline Bulan & $\begin{array}{c}\text { Peralatan } \\
\text { Trip/Out }\end{array}$ & $\begin{array}{c}\text { Jumlah } \\
\text { Gangguan } \\
\text { (Kali) }\end{array}$ & $\begin{array}{c}\text { Lama } \\
\text { Padam } \\
\text { (Jam) }\end{array}$ & SAIFI & SAIDI \\
\hline Jan & - & 0 & 0 & 0 & 0 \\
\hline Feb & PMT & 1 & 0,06 & 1 & 0,06 \\
\hline Mar & - & 0 & 0 & 0 & 0 \\
\hline Apr & - & 0 & 0 & 0 & 0 \\
\hline Mei & - & 0 & 0 & 0 & 0 \\
\hline Jun & - & 0 & 0 & & 0 \\
\hline Jul & - & 0 & 0 & 0 & 0 \\
\hline Agu & - & 0 & 0 & 0 & 0 \\
\hline Sept & PMT & 1 & 0,24 & 1 & 0,24 \\
\hline Okt & - & 0 & 0 & 0 & 0 \\
\hline Nov & - & 0 & 0 & 0 & 0 \\
\hline Des & - & 0 & 0 & & \\
\hline Total & & 2 & 0.30 & 2 & 0.30 \\
\hline
\end{tabular}

Dari hasil perhitungan diperoleh nilai SAIFI dan SAIDI penyulang Imam Bonjol sebelum pemasangan LBS Three Way nilai SAIFI sebesar $2 \mathrm{kali} /$ pelanggan/tahun, untuk SAIDI sebesar $0.30 \mathrm{jam} /$ pelanggan/tahun.

\section{Analisa SAIFI dan SAIDI Berdasarkan Angka Keluaran}

Setelah pemasangan LBS Three Way pada pertemuan penyulang Gunung Agung dan Imam Bonjol maka konfigurasi jaringan antara kedua penyulang tersebut sesuai dengan gambar 5 Pada LBS Three Way, line 1 terhubung pada penyulang Gunung Agung, line 2 terhubung pada penyulang Imam Bonjol dan line 3 terhubung dengan 1 buah pelanggan DB0133 (United Overseas Bank) dari penyulang Gunung Agung, penempatan LBS Three Way (Wahidin) berlokasi di Jalan Wahidin depan United Overseas Bank (UOB).

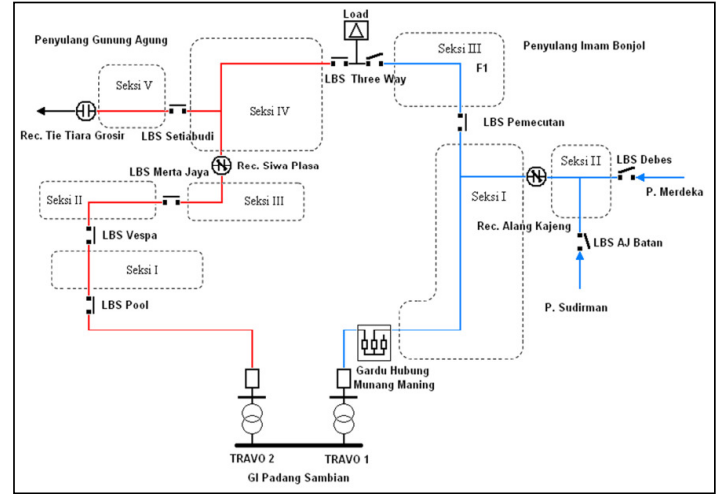

Gambar 3: Loop Scheme Penyulang Gunung Agung dan Imam Bonjol

Menghitung Keandalan Penyulang Gunung Agung Berdasarkan Angka Keluaran. Data yang digunakan untuk menghitung tingkat keandalan penyulang Gunung Agung yaitu jenis komponen, jumlah pelanggan, panjang komponen

I Kadek Hery Samudra : Studi Peningkatan Kualitas Pelayanan ... 
dan untuk data angka keluaran komponen menggunakan acuan dari SPLN.

1) Perhitungan keandalan penyulang gunung agung sebelum pemasangan LBS three way berdasarkan angka keluaran dapat di jelaskan sebagai berikut :

TABEL V

MENGHITUNG KEANDALAN TITIK BEBAN 1 (DB0585) PENYULANG GUNUNG AGUNG

\begin{tabular}{|l|r|r|r|r|r|}
\hline \multicolumn{7}{|c|}{ Titik Beban (DB0585) } \\
\hline $\begin{array}{c}\text { Jenis } \\
\text { Kompo- } \\
\text { nen }\end{array}$ & $\begin{array}{c}\mathrm{n} \\
\begin{array}{c}\text { Kompo- } \\
\text { nen } \\
\text { (unit,km) }\end{array}\end{array}$ & $\begin{array}{c}\text { angka } \\
\text { keluar- } \\
\text { an } \\
\mathrm{m}\end{array}$ & $\begin{array}{c}\text { Laju } \\
\text { Kegagal- } \\
\text { an } \\
\kappa=\mathrm{n} \mathrm{x} \mathrm{m}\end{array}$ & $\begin{array}{c}\text { waktu } \\
\text { perbaik- } \\
\text { an } \\
\mathrm{r} \text { (jam) }\end{array}$ & $\begin{array}{c}\text { Ketidakter- } \\
\text { sediaan } \\
\mathrm{U}=\kappa \mathrm{x} \mathrm{r}\end{array}$ \\
\hline CB & 1 & 0.004 & 0.004 & 10 & 0.04 \\
\hline L1 & 0.519 & 0.7 & 0.3633 & 10 & 3.633 \\
\hline L2 & 0.119 & 0.2 & 0.0238 & 3 & 0.0714 \\
\hline LBS Poll & 1 & 0.004 & 0.004 & 10 & 0.04 \\
\hline L3 & 0.458 & 0.2 & 0.0916 & 3 & 0.2748 \\
\hline L4 & 0.059 & 0.2 & 0.0118 & 3 & 0.0354 \\
\hline Fuse & 1 & 0.004 & 0.004 & 10 & 0.04 \\
\hline Trafo & 1 & 0.005 & 0.005 & 10 & 0.05 \\
\hline Fuse & 1 & 0.004 & 0.004 & 10 & 0.04 \\
\hline
\end{tabular}

\begin{tabular}{|c|c|}
\hline Laju kegagalan $(\kappa)$ total & 0.5115 \\
\hline Waktu perbaikan $(\mathrm{r})$ total & 8.2592375 \\
\hline Ketidaktersediaan tahunan $(\mathrm{U})$ total & 4.2246 \\
\hline Jumlah pelanggan & 2 \\
\hline
\end{tabular}

Dengan cara yang sama diperoleh nilai titik beban yang lain pada penyulang Gunung Agung didapatkan hasil :

TABEL VI

HASIL PERHITUNGAN KEANDALAN PENYULANG GUNUNG AGUNG PER TITIK BEBAN

\begin{tabular}{|c|c|c|c|c|c|c|}
\hline $\begin{array}{c}\text { Titik } \\
\text { Beban }\end{array}$ & $\lambda$ & $\mathbf{r}$ & $\mathbf{u}$ & $\mathbf{m}$ & $\lambda * \mathbf{m}$ & $\mathbf{u} * \mathbf{m}$ \\
\hline Load 1 & 0.5115 & 8.2592 & 4.224 & 2 & 1.023 & 8.4492 \\
\hline Load 2 & 0.5573 & 7.8270 & 4.362 & 1 & 0.5573 & 4.362 \\
\hline & ....... & ...... & $\ldots$ & $\ldots .$. & $\ldots \ldots$ & \\
\hline Load 29 & 1.0639 & 5.6140 & 5.972 & 76 & 80.856 & 453.932 \\
\hline Load 30 & 1.0887 & 5.5545 & 6.047 & 1 & 1.0887 & 6.0472 \\
\hline \multicolumn{4}{|c|}{ Pelanggan terlayani $(\Sigma \mathrm{m})$} & 3364 & & \\
\hline \multicolumn{4}{|c|}{$\operatorname{Pemadaman}(\Sigma(\lambda \times \mathbf{m}))$} & & 3329.2 & \\
\hline \multicolumn{4}{|c|}{$\operatorname{Jam}(\boldsymbol{\Sigma}(\mathbf{u} \times \mathbf{m}))$} & & & 19300.9 \\
\hline
\end{tabular}

Berdasarkan persamaan (2), maka dapat dihitung SAIFI pada penyulang Gunung Agung sebelum pemasangan LBS Three Way:

$$
\begin{aligned}
\text { SAIFI } & =[\boldsymbol{\Sigma}(\boldsymbol{\lambda} \times \mathbf{m})] / \mathbf{\Sigma} \mathbf{m} \\
& =3329.297 / 3364 \\
& =0.989683948(\mathrm{kali} / \text { pelanggan/tahun })
\end{aligned}
$$

Berdasarkan persamaan (4), maka dapat dihitung SAIDI pada penyulang Gunung Agung sebelum pemasangan LBS Three Way :

$$
\begin{aligned}
\text { SAIDI } & =[\mathbf{\Sigma}(\mathbf{u} \times \mathbf{m})] / \mathbf{\Sigma m} \\
& =19300.98 / 3364 \\
& =5.737508561(\mathrm{jam} / \text { pelanggan/tahun })
\end{aligned}
$$

2) Perhitungan keandalan penyulang gunung agung setelah

\begin{tabular}{|c|c|c|c|c|c|c|}
\hline $\begin{array}{c}\text { Titik } \\
\text { Beban }\end{array}$ & $\lambda$ & $\mathbf{r}$ & $\mathbf{u}$ & $\mathbf{m}$ & $\lambda * \mathbf{m}$ & $\mathbf{u} * \mathbf{m}$ \\
\hline Load 1 & 0.5115 & 8.2592 & 4.224 & 2 & 1.023 & 8.4492 \\
\hline Load 2 & 0.5573 & 7.8270 & 4.362 & 1 & 0.5573 & 4.362 \\
\hline & & & & $\cdots$ & & \\
\hline Load 29 & 1.0639 & 5.6140 & 5.972 & 76 & 80.856 & 453.932 \\
\hline Load 30 & 1.1041 & 5.5442 & 6.121 & 1 & 1.1041 & 6.1214 \\
\hline \multicolumn{4}{|c|}{ Pelanggan terlayani ( $\Sigma \mathrm{m}$ ) } & 3364 & & \\
\hline \multicolumn{4}{|c|}{ Pemadaman $(\Sigma(\lambda \times \mathbf{m}))$} & & 3329.3 & \\
\hline \multicolumn{4}{|c|}{$\operatorname{Jam}(\boldsymbol{\Sigma}(\mathbf{u} \times \mathbf{m}))$} & & & 19301.0 \\
\hline
\end{tabular}
pemasangan LBS three way berdasarkan angka keluaran dapat dijelaskan sebagau berikut:

TABEL VII

HASIL PERHITUNGAN KEANDALAN PENYULANG GUNUNG AGUNG PER TITIK BEBAN

Berdasarkan persamaan (2), maka dapat dihitung SAIFI pada penyulang Gunung Agung setelah pemasangan LBS Three Way:

$$
\begin{aligned}
\text { SAIFI } & =[\boldsymbol{\Sigma}(\boldsymbol{\lambda} \times \mathbf{m})] / \mathbf{\Sigma} \mathbf{m} \\
& =3329.3122 / 3364 \\
& =0.989688526(\mathrm{kali} / \text { pelanggan } / \text { tahun })
\end{aligned}
$$

Berdasarkan persamaan (4), maka dapat dihitung SAIDI pada penyulang Gunung Agung setelah pemasangan LBS Three Way :

$$
\begin{aligned}
\text { SAIDI } & =[\boldsymbol{\Sigma}(\mathbf{u} \times \mathbf{m})] / \mathbf{\Sigma} \mathbf{m} \\
& =19301.053 / 3364 \\
& =5.737530618(\mathrm{jam} / \text { pelanggan/tahun })
\end{aligned}
$$

TABEL VIII

HASIL PERHITUNGAN SAIFI DAN SAIDI PENYULANG GUNUNG AGUNG SEBELUM DAN SETELAH PEMASANGAN LBS THREE WAY

\begin{tabular}{|c|c|c|c|c|}
\hline \multirow{2}{*}{ No } & \multicolumn{2}{|c|}{ Sebelum Pemasangan LBS } & \multicolumn{2}{c|}{ Setelah Pemasangan LBS } \\
\cline { 2 - 5 } & $\begin{array}{c}\text { SAIFI } \\
(\text { Kali/plg/thn })\end{array}$ & $\begin{array}{c}\text { SAIDI } \\
(\mathrm{Jam} / \mathrm{plg} / \mathrm{thn})\end{array}$ & $\begin{array}{c}\text { SAIFI } \\
(\mathrm{Kali} / \mathrm{plg} / \mathrm{thn})\end{array}$ & $\begin{array}{c}\text { SAIDI } \\
(\mathrm{Jam} / \mathrm{plg} / \mathrm{thn})\end{array}$ \\
\hline 1 & 0,989683948 & 5,737508561 & 0,98968852 & 5,737530618 \\
\hline
\end{tabular}

3) Perhitungan Keandalan Penyulang Imam Bonjol sebelum Pemasangan LBS Three Way Berdasarkan Angka Keluaran

I Kadek Hery Samudra : Studi Peningkatan Kualitas Pelayanan ... 
TABEL $\mathrm{X}$

DATA KEANDALAN TITIK BEBAN 1 (DB0177) PENYULANG IMAM BONJOL

\begin{tabular}{|c|c|c|c|c|c|}
\hline \multicolumn{6}{|c|}{ Titik Beban (DB0177) } \\
\hline $\begin{array}{c}\text { Jenis } \\
\text { Kompon } \\
\text { en }\end{array}$ & $\begin{array}{c}\mathrm{n} \\
\text { Kompon } \\
\text { en } \\
\text { (unit,km) }\end{array}$ & $\begin{array}{c}\text { angka } \\
\text { keluara } \\
\mathrm{n} \mathrm{m}\end{array}$ & \begin{tabular}{c}
\multicolumn{2}{c}{ Laju } \\
Kegagal \\
an $\quad \Lambda$ \\
$=\mathrm{n} \times \mathrm{m}$ \\
\end{tabular} & $\begin{array}{c}\text { waktu } \\
\text { perbaik } \\
\text { an } r \\
\text { (jam) } \\
\end{array}$ & $\begin{array}{c}\text { Ketidakterse } \\
\text { diaan } \\
\mathrm{U}=\Lambda \mathrm{x} \mathrm{r}\end{array}$ \\
\hline $\mathrm{CB}$ & 1 & 0.004 & 0.004 & 10 & 0.04 \\
\hline L1 & 0.345 & 0.7 & 0.069 & 10 & 0.207 \\
\hline $\mathrm{L} 2$ & 0.241 & 0.2 & 0.0482 & 3 & 0.1446 \\
\hline $\mathrm{GH}$ & 1 & 0.005 & 0.005 & 10 & 0.05 \\
\hline L3 & 0.810 & 0.2 & 0.162 & 3 & 0.486 \\
\hline L4 & 0.169 & 0.2 & 0.0338 & 3 & 0.1014 \\
\hline L5 & 0.035 & 0.2 & 0.007 & 3 & 0.021 \\
\hline Fuse & 1 & 0.004 & 0.004 & 10 & 0.04 \\
\hline Trafo & 1 & 0.005 & 0.005 & 10 & 0.05 \\
\hline Fuse & 1 & 0.004 & 0.004 & 10 & 0.04 \\
\hline \multicolumn{5}{|c|}{ Laju kegagalan $(\Lambda)$ total } & \\
\hline \multicolumn{4}{|c|}{ Waktu perbaikan $(\mathrm{r})$ total } & 6.585034 & \\
\hline \multicolumn{4}{|c|}{ Ketidaktersediaan tahunan ( U ) total } & 3.3880 & \\
\hline \multicolumn{4}{|c|}{ Jumlah pelanggan } & 77 & \\
\hline
\end{tabular}

Dengan cara yang sama diperoleh nilai titik beban yang lain pada penyulang Imam Bonjol didapatkan hasil :

TABEL XI

HASIL PERHITUNGAN KEANDALAN PENYULANG IMAM BONJOL PER TITIK BEBAN

\begin{tabular}{|c|c|c|c|c|c|c|}
\hline $\begin{array}{c}\text { Titik } \\
\text { Beban }\end{array}$ & $\lambda$ & $\mathbf{r}$ & $\mathbf{u}$ & $\mathbf{m}$ & $\lambda * \mathbf{m}$ & $\mathbf{u} * \mathbf{m}$ \\
\hline Load 1 & 0.5145 & 6.5850 & 3.388 & 77 & $\begin{array}{c}39.616 \\
5\end{array}$ & 260.87 \\
\hline Load 2 & 0.5313 & 6.4716 & 3.438 & 87 & $\begin{array}{c}46.223 \\
1\end{array}$ & 299.14 \\
\hline$\ldots \ldots \ldots$ & ...... & $\ldots \ldots$ & ....... & $\ldots$ & $\ldots \ldots$ & $\ldots \ldots \ldots$ \\
\hline Load 23 & 0.6545 & 5.8609 & 3.836 & 26 & 17.017 & 99.73 \\
\hline Load 24 & 0.6803 & 5.7524 & 3.913 & 171 & 116.33 & 669.19 \\
\hline \multicolumn{4}{|c|}{ Pelanggan terlayani $(\Sigma \mathrm{m})$} & 2987 & & \\
\hline \multicolumn{4}{|c|}{ Pemadaman $(\Sigma(\lambda \times \mathbf{m}))$} & & 2042.8 & \\
\hline \multicolumn{4}{|c|}{$\operatorname{Jam}(\boldsymbol{\Sigma}(\mathbf{u} \times \mathbf{m}))$} & & & 11673.8 \\
\hline
\end{tabular}

Berdasarkan persamaan (2), maka dapat dihitung SAIFI pada penyulang Imam Bonjol sebelum pemasangan LBS Three Way:

$$
\begin{aligned}
\text { SAIFI } & =[\Sigma(\lambda \times \mathrm{m})] / \Sigma \mathrm{m} \\
& =2042.8279 / 2987 \\
& =0.68390623(\mathrm{kali} / \text { pelanggan/tahun })
\end{aligned}
$$

Berdasarkan persamaan (4), maka dapat dihitung SAIFI pada penyulang Imam Bonjol sebelum pemasangan LBS Three Way :

$$
\begin{aligned}
\text { SAIDI } & =[\Sigma(\mathrm{u} \times \mathrm{m})] / \Sigma \mathrm{m} \\
& =11673.8172 / 2987 \\
& =3.90820797(\mathrm{jam} / \text { pelanggan/tahun })
\end{aligned}
$$

4) Perhitungan Keandalan Penyulang Imam Bonjol Setelah

\begin{tabular}{|c|c|c|c|c|c|c|}
\hline $\begin{array}{c}\text { Titik } \\
\text { Beban } \\
\end{array}$ & $\lambda$ & $\mathbf{r}$ & $\mathbf{u}$ & $\mathbf{m}$ & $\lambda * \mathbf{m}$ & $\mathbf{u} * \mathbf{m}$ \\
\hline Load 1 & 0.5145 & 6.5850 & 3.388 & 77 & 39.616 & 260.876 \\
\hline Load 2 & 0.5313 & 6.4716 & 3.438 & 87 & 46.223 & 299.140 \\
\hline ..... & & ........ & $\ldots$ & ....... & .... & ... \\
\hline Load 24 & 0.6803 & 5.7524 & 3.913 & 171 & 116.33 & 669.191 \\
\hline Load 25 & 0.7049 & 5.6961 & 4.015 & 1 & 0.704 & 4.0152 \\
\hline \multicolumn{4}{|c|}{ Pelanggan terlayani ( $\Sigma \mathrm{m})$} & 2988 & & \\
\hline \multicolumn{4}{|c|}{ Pemadaman $(\Sigma(\lambda \times \mathbf{m}))$} & & 2043.5 & \\
\hline \multicolumn{4}{|c|}{$\operatorname{Jam}(\boldsymbol{\Sigma}(\mathbf{u} \times \mathbf{m}))$} & & & 11677.8 \\
\hline
\end{tabular}
Pemasangan LBS Three Way Berdasarkan Angka Keluaran

TABEL XII

HASIL PERHITUNGAN KEANDALAN PENYULANG IMAM BONJOL PER TITIK BEBAN

Berdasarkan persamaan 2.3, maka dapat dihitung SAIFI pada penyulang Imam Bonjol setelah pemasangan LBS Three Way:

$$
\begin{aligned}
\text { SAIFI } & =[\Sigma(\lambda \times \mathrm{m})] / \Sigma \mathrm{m} \\
& =2043.5328 / 2988 \\
& =0.683913253(\mathrm{kali} / \text { pelanggan } / \text { tahun })
\end{aligned}
$$

Berdasarkan persamaan 2.6, maka dapat dihitung SAIFI pada penyulang Imam Bonjol setelah pemasangan LBS Three Way:

$$
\begin{aligned}
\text { SAIDI } & =[\Sigma(\mathrm{u} \times \mathrm{m})] / \Sigma \mathrm{m} \\
& =11677.8324 / 2988 \\
& =3.908243775(\mathrm{jam} / \text { pelanggan/tahun })
\end{aligned}
$$

TABEL XIII

HASIL PERHITUNGAN SAIFI DAN SAIDI PENYULANG IMAM BONJOL SEBELUM DAN SETELAH PEMASANGAN LBS THREE WAY

\begin{tabular}{|c|c|c|c|c|}
\hline \multirow{2}{*}{ No } & \multicolumn{2}{|c|}{ Sebelum Pemasangan LBS } & \multicolumn{2}{c|}{ Setelah Pemasangan LBS } \\
\cline { 2 - 5 } & $\begin{array}{c}\text { SAIFI } \\
(\text { Kali/plg/thn) }\end{array}$ & $\begin{array}{c}\text { SAIDI } \\
(\mathrm{Jam} / \mathrm{plg} / \mathrm{thn})\end{array}$ & $\begin{array}{c}\text { SAIFI } \\
(\text { Kali/plg/thn })\end{array}$ & $\begin{array}{c}\text { SAIDI } \\
(\mathrm{Jam} / \mathrm{plg} / \mathrm{thn})\end{array}$ \\
\hline 1 & 0.68390623 & 3.90820797 & 0.68390623 & 3.908243775 \\
\hline
\end{tabular}

\section{Analisa Pengaruh Pemasangan LBS Three Way Terhadap Mutu Pelayanan Pelanggan DB0133 (United Overseas Bank)}

Dari hasil menganalisa jumlah dan lama pemadaman, sebelum dan setelah pemasangan LBS Three Way pada pelanggan khususnya DB0133 (United Overseas Bank) yang terhubung langsung dengan LBS Three Way. Maka dapat dilihat pengaruh pemasangan dari LBS Three Way terhadap kualitas pelayanan pada pelanggan.

Pada tabel 14 dapat dijelaskan pada tahun 2012 sebelum pemasangan LBS Three Way, pelanggan DB0133 (United Overseas Bank) mengalami pemadaman sebesar 6.348 kali/pelanggan/tahun dan lama pemadaman sebesar 9.519 jam/pelanggan/tahun. Hal tersebut dikarenakan pada tahun 2012 sebelum pemasangan LBS Three Way pelanggan DB0133 (United Overseas Bank) masih terhubung langsung pada penyulang Gunung Agung, sehingga apabila terjadi gangguan pada penyulang gunung agung maka pelanggan DB0133 (United Overseas Bank) ikut mengalami pemadaman.

I Kadek Hery Samudra : Studi Peningkatan Kualitas Pelayanan ... 
Pada tahun 2014 setelah pemasangan LBS Three Way, pelanggan DB0133 (United Overseas Bank) tidak mengalami gangguan karena saat terjadi gangguan pada penyulang Gunung Agung, pelanggan DB0133 (United Overseas Bank) lepas dari penyulang Gunung Agung dan terhubung dengan penyulang Imam Bonjol sehingga pelanggan DB0133 (United Overseas Bank) tetap mendapat supply daya dari penyulang Imam Bonjol.

TABEL XIV

PENGARUH PEMASANGAN LBS THREE WAY TERHADAP MUTU PELAYANAN PELANGGAN DB0133 PADA PENYULANG GUNUNG AGUNG BERDASARKAN DATA GANGGUAN

\begin{tabular}{|c|c|c|c|c|}
\hline B & \multicolumn{2}{|c|}{ SAIFI (Kali/plg/thn) } & \multicolumn{2}{|c|}{ SAIDI ( Jam/plg/thn) } \\
\hline $\begin{array}{l}\mathrm{u} \\
\mathrm{l} \\
\mathrm{a} \\
\mathrm{n}\end{array}$ & $\begin{array}{l}\text { Sebelum } \\
\text { Pemasangan } \\
\text { LBS }\end{array}$ & $\begin{array}{c}\text { Setelah } \\
\text { Pemasangan } \\
\text { LBS }\end{array}$ & $\begin{array}{c}\text { Sebelum } \\
\text { Pemasangan } \\
\text { LBS }\end{array}$ & $\begin{array}{c}\text { Setelah } \\
\text { Pemasangan } \\
\text { LBS }\end{array}$ \\
\hline Jan & 2 & 0 & 7,24 & 0 \\
\hline Feb & 0 & 0 & 0 & 0 \\
\hline Mar & 0 & 0 & 0 & 0 \\
\hline Apr & 0 & 0 & 0 & 0 \\
\hline Mei & 0 & 0 & 0 & 0 \\
\hline Juni & 2 & 0 & 0,34 & 0 \\
\hline Jul & 0 & 0 & 0 & 0 \\
\hline Agu & 0 & 0 & 0 & 0 \\
\hline Sep & 1 & 0 & 0,34 & 0 \\
\hline Okt & 0,018 & 0 & 0,025 & 0 \\
\hline Nov & 1,33 & 0 & 1,57 & 0 \\
\hline Des & 0 & 0 & 0 & 0 \\
\hline Total & 6,348 & 0 & 9,519 & 0 \\
\hline
\end{tabular}

E. Analisa manuver pelanggan DB0133 (United Overseas Bank) Dari Penyulang Gunung Agung Ke Penyulang Imam Bonjol

Dari menganalisa perpindahan pelanggan DB0133 (United Overseas Bank) penyulang Gunung Agung ke penyulang Imam Bonjol, maka dapat diketahui pengaruh pembebanan pada penyulang Imam Bonjol saat memanuver daya ke pelanggan DB0133 (United Overseas Bank). Pengaruh perpindahan pelanggan DB133 (United Overseas Bank) dari penyulang Gunung Agung ke penyulang Imam Bonjol dapat dihitung sebagai berikut :

1) Daya terpasang penyulang Imam Bonjol setelah manuver

DB133 (United Overseas Bank).

Daya = Daya terpasang penyulang Imam Bonjol + Daya terpasang DB133 (United Overseas Bank)

$=5,962 \mathrm{kVA}+250 \mathrm{kVA}$

$=6,212 \mathrm{kVA}$

2) Arus penyulang Imam Bonjol setelah manuver DB133 (United Overseas Bank).

$$
\begin{aligned}
S & =\sqrt{3} \times \mathrm{V} \times \mathrm{I} \\
I & =\frac{\mathrm{S}}{\sqrt{3} \mathrm{xV}} \\
I & =\frac{6,212 \mathrm{kVA}}{\sqrt{3 \times 20 \mathrm{kV}}} \\
I & =179.33 \text { Ampere }
\end{aligned}
$$

Dari hasil perhitungan diatas, daya terpasang pada penyulang Imam Bonjol setelah pelanggan DB133 (United Overseas Bank) masuk ke penyulang Imam Bonjol sebesar 6,212 kVA dan Arus sebesar 179.33 Ampere, sehingga penyulang Imam Bonjol masih mampu untuk melayani daya terpasang setelah manuver pelanggan DB133, karena dilihat dari jenis penghantar yang digunakan pada penyulang Imam Bonjol yaitu NA2XSEBY 3x150mm2 dengan nilai KHA sebesar 294 Ampere.

\section{F. Analisa Kemampuan Manuver Beban Penyulang Imam Bonjol Setelah Pemasangan LBS Three Way}

Dari hasil perhitungan diatas, daya terpasang pada penyulang Imam Bonjol setelah manuver seksi IV dan $\mathrm{V}$ penyulang Gunung Agung sebesar 7,908 kVA dan nilai arus sebesar 228.92 Ampere, sehingga penyulang Imam Bonjol dapat dikatakan mampu untuk melayani beban setelah manuver seksi IV dan V penyulang Gunung Agung.

TABEL XV

HASIL PERHITUNGAN DAYA TERPASANG DAN ARUS PADA PENYULANG GUNUNG AGUNG DAN IMAM BONJOL

\begin{tabular}{|c|c|c|c|c|}
\hline \multirow{2}{*}{ No } & \multicolumn{2}{|c|}{$\begin{array}{c}\text { Penyulang Gunung Agung } \\
\text { Manuver Seksi I dan III P. } \\
\text { Imam Bonjol }\end{array}$} & \multicolumn{2}{|c|}{$\begin{array}{c}\text { Penyulang Imam Bonjol } \\
\text { Manuver Seksi III, IV dan V P. } \\
\text { Gunung Agung }\end{array}$} \\
\cline { 2 - 5 } & $\begin{array}{c}\text { Daya } \\
\text { terpasang } \\
\text { (kVA) }\end{array}$ & $\begin{array}{c}\text { Arus } \\
\text { (Ampere) }\end{array}$ & $\begin{array}{c}\text { Daya } \\
\text { terpasang } \\
\text { (kVA) }\end{array}$ & $\begin{array}{c}\text { Arus } \\
\text { (Ampere) }\end{array}$ \\
\hline 1 & 9,881 & 285.24 & 9,293 & 268.27 \\
\hline
\end{tabular}

Dari hasil perhitungan diatas diperoleh daya terpasang penyulang Gunung Agung setelah manuver beban pada seksi I dan III penyulang Imam Bonjol sebesar 9,881 kVA dan arus sebesar 285.24 Ampere, sedangkan pada penyulang Imam Bonjol setelah manuver beban pada seksi III, IV dan V penyulang Gunung Agung diperoleh daya terpasang sebesar 9,293 kVA dan arus sebesar 268.27 Ampere.

\section{KESIMPULAN}

Dari hasil pembahasan dan analisa yang telah dilakukan maka dapat disampaikan beberapa simpulan antara lain:

1) Pemasangan LBS Three Way dapat meningkatkan kualitas pelayanan pelanggan khususnya DB0133 (United Overseas Bank), hal ini dilihat dari hasil analisa pada tahun 2012 sebelum pemasangan LBS Three Way, pelanggan DB0133 (United Overseas Bank) mengalami pemadaman sebesar $6.348 \mathrm{kali} /$ pelanggan/tahun dan lama pemadaman sebesar $9.519 \mathrm{jam} /$ pelanggan/tahun dan Pada tahun 2014 setelah pemasangan LBS Three Way, pelanggan DB0133 (United Overseas Bank) tidak mengalami gangguan karena saat terjadi gangguan pada penyulang Gunung Agung, pelanggan DB0133 (United Overseas Bank) lepas dari penyulang Gunung Agung dan terhubung dengan penyulang Imam Bonjol sehingga pelanggan DB0133 (United Overseas Bank) tetap mendapat supply daya dari penyulang Imam Bonjol. 
2) Berdasarkan hasil perhitungan kemampuan manuver beban penyulang Gunung Agung dan Imam Bonjol. Daya terpasang pada penyulang Gunung Agung setelah manuver seksi I dan III penyulang Imam Bonjol sebesar 9,881 kVA dan nilai arus sebesar 285.24 Ampere, dan daya terpasang pada penyulang Imam Bonjol setelah manuver seksi III, IV dan V penyulang Gunung Agung sebesar 9,293 kVA dengan nilai arus sebesar 268.27 Ampere. Maka dapat disimpulkan bahwa penyulang Gunung Agung mampu memanuver sampai seksi I dan III penyulang Imam Bonjol dan penyulang Imam Bonjol mampu memanuver sampai seksi III, IV dan V penyulang Gunung Agung.

\section{REFERENSI}

[1] Billinton, R.,J.E.1989. Distribution System Reliability Indices, IEEE Trans. Power Delivery, vol.4.

[2] PT PLN (Persero). 2005. Power System Engeneering Bidang Distribusi : Keandalan Sistem Distribusi. Palembang : PT PLN (Persero) Jasa Pendidikan dan Pelatihan.

[3] Jendra. 2010. Analisa Pengaruh Pemasangan Recloser Tie Pada Penyulang Blahkiuh - Panglan Terhadap Mutu Pelayanan. Denpasar : Universitas Udayana.

[4] Gonen, Turan. 1986. Elektrical Power Distribution System Engeneering. USA : McGraw-Hill

[5] Tim Kajian Perencanaan Sistem Distribusi Tenaga Listrik. 2005. Laporan Akhir Perencanaan Sistem Distribusi Tenaga Listrik. Jimbaran : Jurusan Teknik Elektro Universitas Udayana.

[6] PT PLN (Persero). 1985. SPLN 59 : Keandalan Pada Sistem Distribusi $20 \mathrm{kV}$ dan $6 \mathrm{kV}$. Jakarta : Departeman Pertambangan dan Energi Perusahaan Umum Listrik Negara. 